\title{
Effects of the development of production factors on productivity
}

\author{
András Vántus \\ University of Debrecen Faculty of Agricultural and Food Sciences and Environmental Management, \\ Institute for Land Utilisation, Regional Development and Technology, Debrecen \\ vantus@agr.unideb.hu
}

\begin{abstract}
SUMMARY
In every economic sector, the enacted and expected quality of the products strongly affects its market entry and subsistence. The aim of management is success, competitiveness and subsistence that require adequate human and material resources and enough production stock. We must also notice that the quality of tools and instruments significantly influences work productivity. This applies to both plant production and animal husbandry.

The author researched milk production factors with methodical observation, document analysis and interviews. Data were collected with a ten-year interval, thus this assay can highlight the field, volume and sources of investments during this period and that the production stock increased in most farms and decreased in few. The data also shows the influence of investments on work productivity - there are differences between farms of equal size, so there are still ways of development.
\end{abstract}

Keywords: human factors, objective factors, development, work productivity

\section{ÖSSZEFOGLALASS}

Bármelyik ágazatot vizsgáljuk, az elöállitott termékek elöirt, illetve elvárt minösége és mennyisége eröteljesen befolyásolja a piacra jutási, illetve a piacon maradási lehetőséget. A gazdálkodás célja a sikeresség, a versenyképesség elérése és fenntartása. Ennek érdekében a tevékenység emberi és tárgyi tényezőit, valamint a megfelelö méretü termelö állományt biztositani kell. Meg kell jegyezni, hogy a tárgyi eszközök, berendezések adott minöségi szinvonala jelentösen befolyásolja a munka eredményességét. Ez a megállapitás egyaránt érvényes a növényi eredetü és az állati eredetü élelmiszertermelésre. A szerzö a tejtermelés termelési tényezöit vizsgálta módszeres megfigyeléssel,dokumentum-elemzéssel és a munkahelyi vezetővel folytatott szóbeli interjúval. Az adatgyüjtést 10 éves idöközzel végezte, így a dolgozat bemutatja az idöközben végrehajtott fejlesztések jellegét, volumenét és forrását, de az is kitünik, hogy bizonyos gazdaságokban a termelö állatállomány csökkent, miközben a telepek többségénél növekedés volt tapasztalható. Az is látható az eredményekböl, hogy a fejlesztések milyen hatással voltak a munkatermelékenységre. Megállapitható, hogy a hasonló méretü tehenészetek mutatói között még vannak különbségek, így továbblépésre is lehetőség van.

Kulcsszavak: humán tényezök, tárgyi tényezők, fejlesztés, munkatermelékenység

\section{INTRODUCTION}

Productivity greatly influences competitiveness, but quantity and quality together determines market entry and subsistence. Therefore enterprises should reach high work productivity through optimal use of their resources. Work productivity also indicates the utilization of work force in added value production (Hüttl, 2010), and this utilization is influenced by the quality of technical instruments (Fülöp, 2003). These also apply to agricultural production, because work power and instruments (machines and tools) are important production factors (Net1). Certain products need certain technologies, and instruments and technology define the necessary resources (Salamon et al., 2011). It is unfavourable for the producer, that the market does not always pay for these resources (Popp et al., 2007), thus production costs should be reduced (Net2) - for example by optimal use of technologies (Net3) - and careful planning is necessary (Gulyás and Keczer, 2012).

High intensity is typical of agricultural production (Kupán, 2007) - for example in animal husbandry - and transport and processing also requires high capacities (Sutus, 2012). Technical investments can increase these capacities, but only with trained work force who can apply the investments, and the enterprise can utilize its technical skills (Salamon et al., 2011). That also helps to decrease costs through limiting work costs with decreased time consumption (Gergely, 2011; Bácsné, 2013).

We can conclude that modern technology is a key factor in competitiveness (Harsányi et al., 2005; Hagymássy and Gindert-Kele, 2011; Széles et al., 2012; Sulyok et al., 2013). Professional work force is necessary to operate modern technology, thus implementing and applying modern technology is influenced by the quantity and quality of human resources.

Development is favourable also because modern establishments are safer and this improves work condition that is necessary according to the opinion of agricultural workers (Terjék, 2010). Agricultural production has an increasing interest in areas with lower employment rates (Harsányi et al., 2014), but hopefully regional development of animal husbandry will increase employment (Seregi and Kis, 2014). That is especially important because there is high and permanent unemployment in several regions (Vámosi, 2011; Mezö, 2012). Although some studies show that increased competitiveness does not always raise employment (Vántus and Hagymássy, 2014), still we can state that competitiveness can improve employment and the standard of living that can result in education of work force and improved technical skills (Rózsás, 2007).

Profitability requires development (Harsányi et al., 2014), especially the intensification of economic 
development, because the Northern-Great Plain region used only $12.2 \%$ of the EU regional sources in this field (Nagy et al., 2014). Funding proposals are important sources of technical development and should be utilized (Szabó, 2013). Pierog and Szabados (2012) also emphasizes that organizations should involve foreign resources to become more successful. These funds will also be available in the future because the Hungarian Government started a program to preserve work places - and establish 70000 until 2020 - in the agriculture, including animal husbandry (Net4). The rural areas in Hungary will arise thank to the program that ensures that the small and medium-sized animal husbandry farms will be among the winners of the new budget cycle of the European Union (Net5).

The interest and aim of the farmers is to apply for these funds and improve or change their production factors as needed, because this way they can increase productivity and profitability.

\section{METHODS}

The research was conducted in Hajdú-Bihar County on 6 dairy farms (F1-F6) with a ten-year interval. I assessed the changes of human and technical factors and of the milking cow stock in the past ten years. Data were collected using methodical observation, document analysis and oral interviews. In the case of the technical factor, I surveyed the type of developments, their cost and financial source. I also introduce the influence of technical investments on human resources and cow stock. The results are displayed in table and figures.

\section{RESEARCH}

In the main operations of the process of milk production (milking, feeding, stall grooming and bedding, calving and calf management, grooming, guarding, transportation and other operations) the worker, the cow stock, the conditions and the technical supply is of key importance. Table 1 shows the number of

Table 1

The main data of the dairy farms in the two research years

\begin{tabular}{lcccccccccccc}
\hline \multicolumn{1}{c}{ Farms } & \multicolumn{2}{c}{ F1 } & \multicolumn{2}{c}{ F2 } & \multicolumn{2}{c}{ F3 } & \multicolumn{2}{c}{ F4 } & \multicolumn{2}{c}{ F5 } \\
\hline Research year & 2003 & 2013 & 2003 & 2013 & 2003 & 2013 & 2003 & 2013 & 2003 & 2013 & 2003 & 2013 \\
\hline Cow stock (head of cows) & 570 & 199 & 609 & 247 & 375 & 387 & 380 & 540 & 472 & 572 & 572 & 701 \\
Physical workers (persons) & 19.0 & 7.0 & 31.5 & 15.0 & 26.5 & 24.0 & 12.0 & 16.0 & 21.0 & 16.0 & 30.0 & 22.0 \\
Produced raw milk (millions of litre) & 3.74 & 1.02 & 4.62 & 1.88 & 2.50 & 2.88 & 2.79 & 3.60 & 4.02 & 5.30 & 4.26 & 5.68 \\
\hline
\end{tabular}

physical workers, the number of cows and the amount of raw milk produced, and the changes in the ten-year interval. The number of stock decreased on farm F1 and F2, but increased on the other farms.

The number of cows decreased with $65 \%$ on farm F1 and with $59 \%$ on farm F2, while on the other farms it increased with $3-42 \%$. The number of workers has not decreased as much on F1 and F2 then the number of cows. However, on the farms with increased number of cows the number of physical workers decreased (F3, F5 and F6), or increased less (33\%) than the number of cows $(42 \%)$ (F4). In order to improve their results, the farms implemented developments and investments in grooming and in the technical supply. Farms F1 and F2 - where the number of cows significantly decreased invested less in developments than the other farms (F1: 98.84 million $\mathrm{Ft}, \mathrm{F} 2$ : 10.90 million $\mathrm{Ft}$ ) in the past ten years (Figure 1).

On farm F1 the investments included concrete padding of the manure storage area, slurry channelling, feeder equipment, loader and tractor purchase. F2 invested only in the purchase of feeder equipment. Investments were higher or much higher on the other farms. The costs of investments and their sources on farms F3-F6 are presented in the following (Figure 2).

Figure 1: Source and amount of investments I.

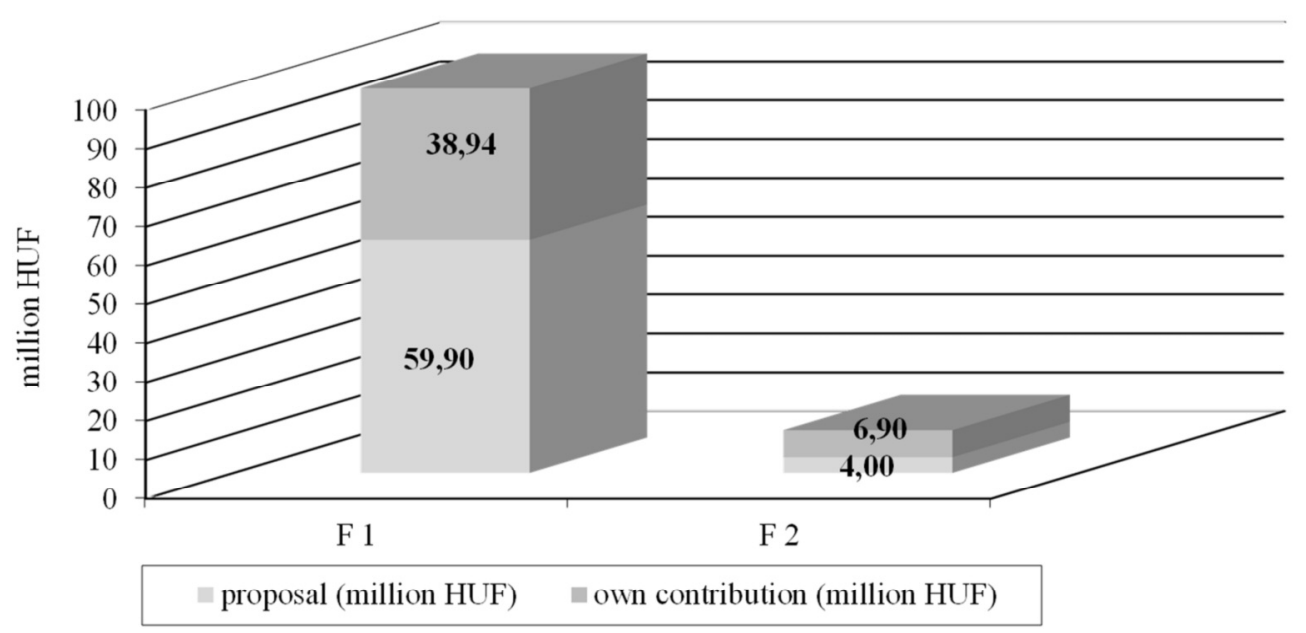

Note: F1; F2: Farms 
Figure 2: Source and amount of investments II.

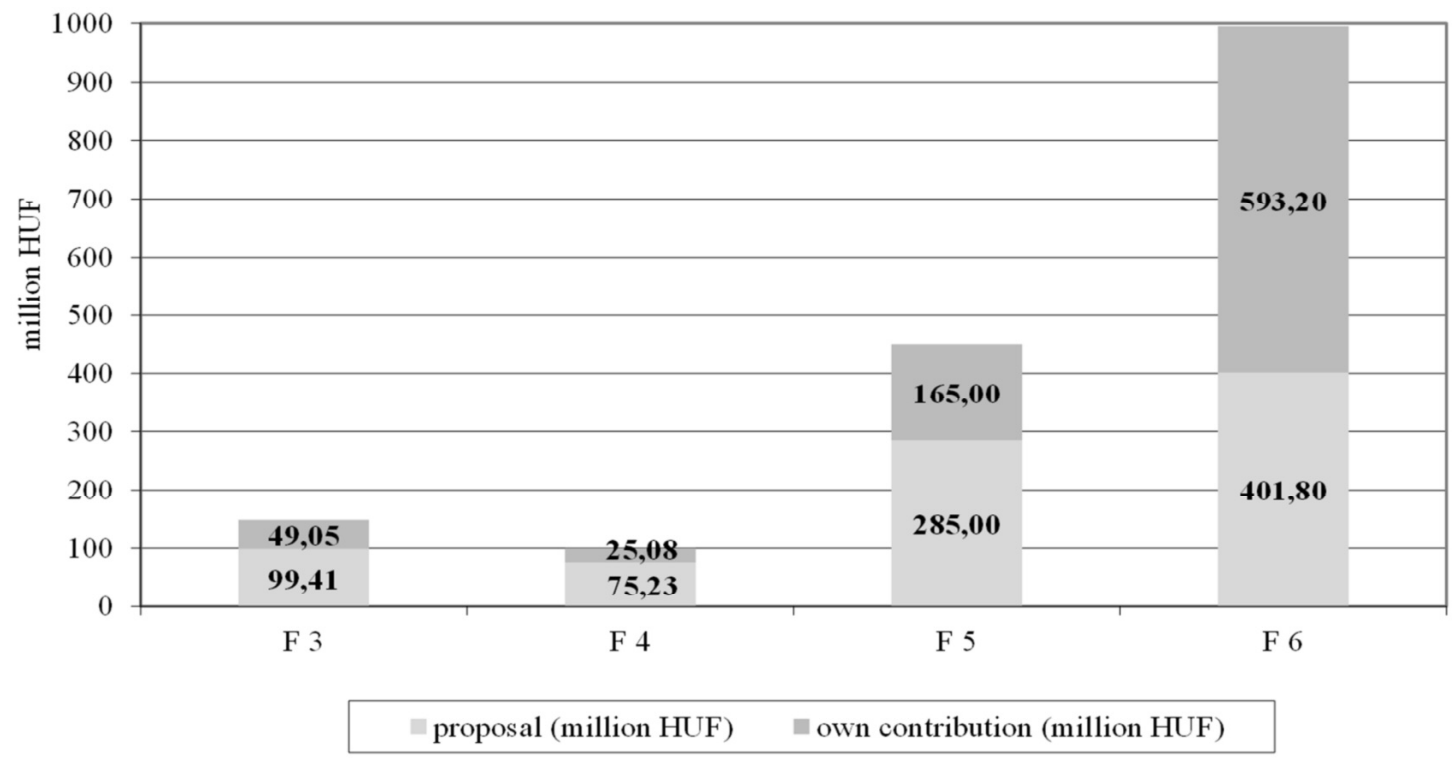

Note: F3; F4; F5; F6: Farms

Figure 2 illustrates the great differences among farm investments in the examined period. While F3 invested about 100 million Ft, then F6 invested almost 1 billion Ft, detailed as follows. F3 repaired the roads, modernized the buildings and the manure storage, purchased machines for manure handling and feeding, and Steimann cages for calf raising. Misting and air circulators improve cow comfort during the summer thus help to increase milk production. F3 also paid for the training of workers that is unusual nowadays because the enterprises try to save on their costs.

Farm F4 invested in manure storage, manure handling machines and tractors, bale chopping, channelling and suction. Farm F5 built a feed storage, slurry and manure storage, modernized buildings and roads. Farm F5 purchased also feeder machines, loaders, tractors, manure scraper, foot bath and cowbrush. Farm F6 made the largest investments including new free stall stables, tractors and loaders, renovated milking equipment and roofs and paid the training of the workers. We must consider that farm F6 could ensure almost 600 million Ft own contribution for these developments. Modernization probably contributed to the decreasing number of physical workers despite the increasing number of cows in three farms. In most cases the investments resulted in increased work productivity as the number of cows per physical workers show (Figure 3).

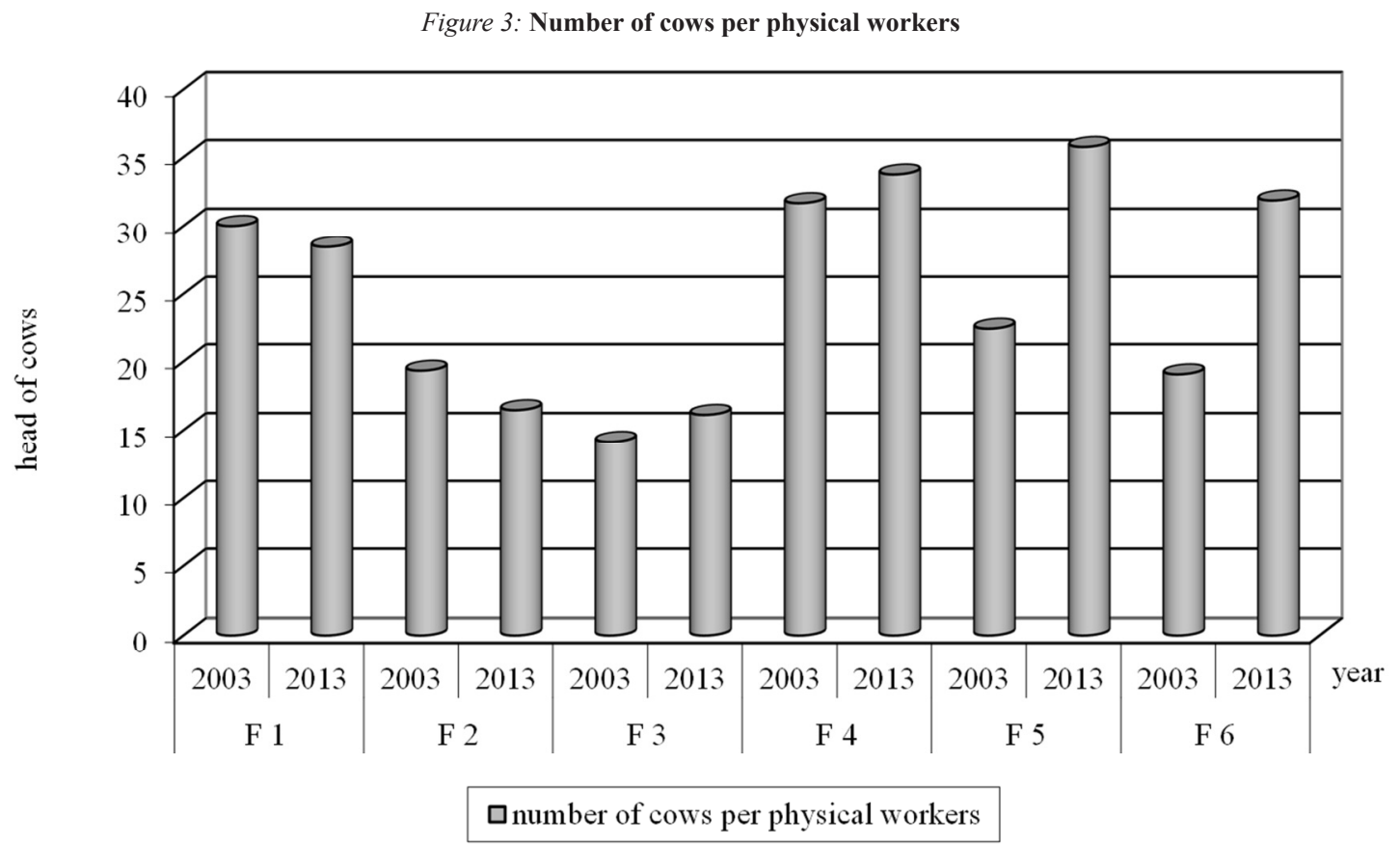

Note: F1; F2; F3; F4; F5; F6: Farms 
Figure 3 shows that work productivity decreased on farms F1 (with 5\%) and F2 (with 15\%), where the number of cows also decreased. On the other farms the number of cows per workers increased between 7-67\%. $67 \%$ increase occurred on farm F6, but the number of cows per workers is the highest on farm F5 (more than 35 cows per workers). The smallest increase occurred on farm F4 but we must highlight that this farm had the best productivity in 2003 and could improve that by 2013 reaching the second place among farms.

The second index of productivity is the work hours per cows per year (Figure 4). It is clearly indicated that time consumption grew in farms $\mathrm{F} 1$ and $\mathrm{F} 2$ with $6 \%$ and $17 \%$, respectively. Still farm F3 has the worst results both in 2003 and 2013, almost double time consumed per cows than on the best farm. Farm F4 has the best and most steady results during the study period. Farm F5 has the best productivity according to time consumption ( 58.35 work hours per cow per year). Figure 4 also shows that all farms F3-F6 decreased their time consumption during the study period.

The third index to measure productivity is the work hours per 100 litres of milk (Figure 5). Time consumption increased the most on farm F1 (35\%), and on farm F2 (17\%). Still farm F3 shows the worst productivity according to this index as well (1.74 hours per 100 litres of milk). Farm F5 consumes the least time for producing 100 litres of milk, only 0.63 work hours. Farm F4 had the best result in 2003 and increased its consumption only with $3 \%$ by 2013 .

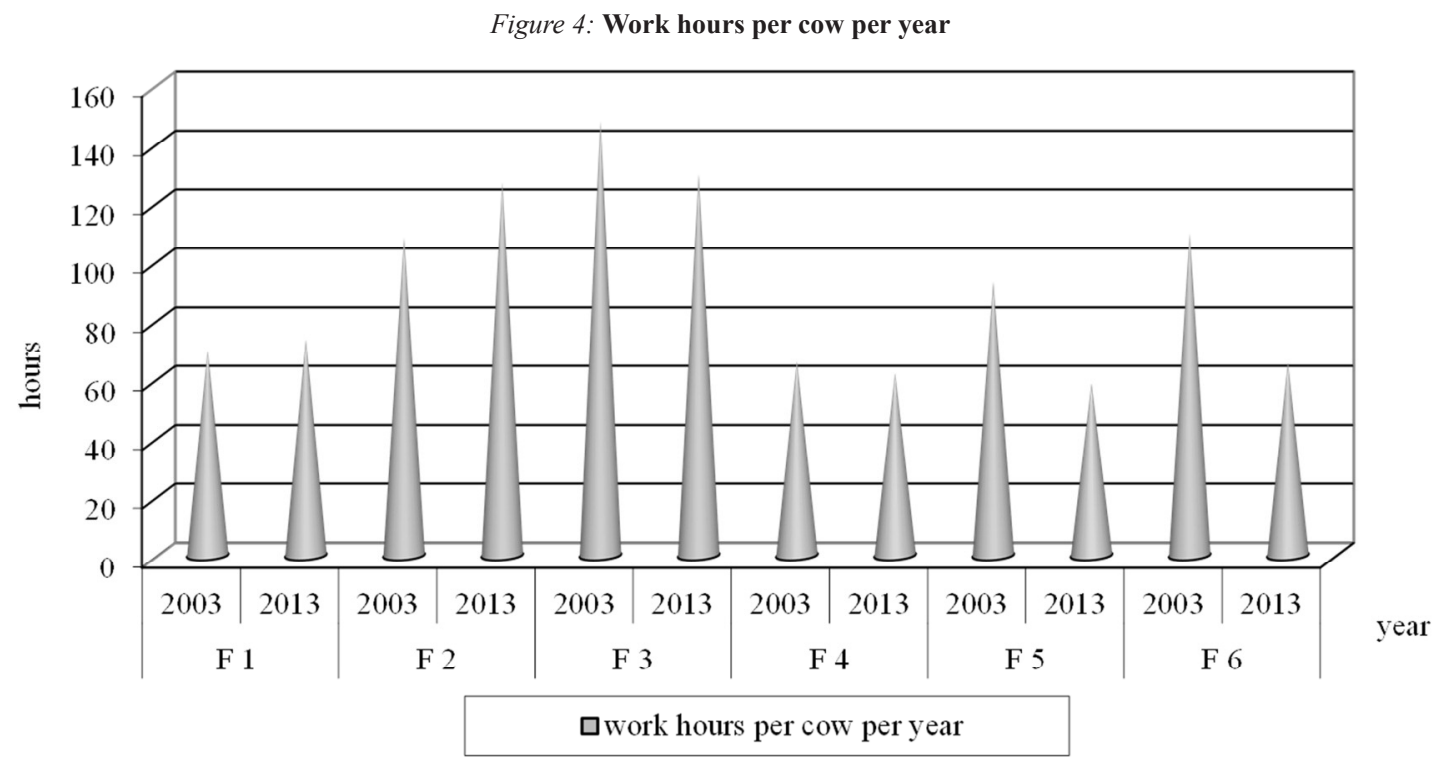

Note: F1; F2; F3; F4; F5; F6: Farms

Figure 5: Work hours per 100 litres of milk

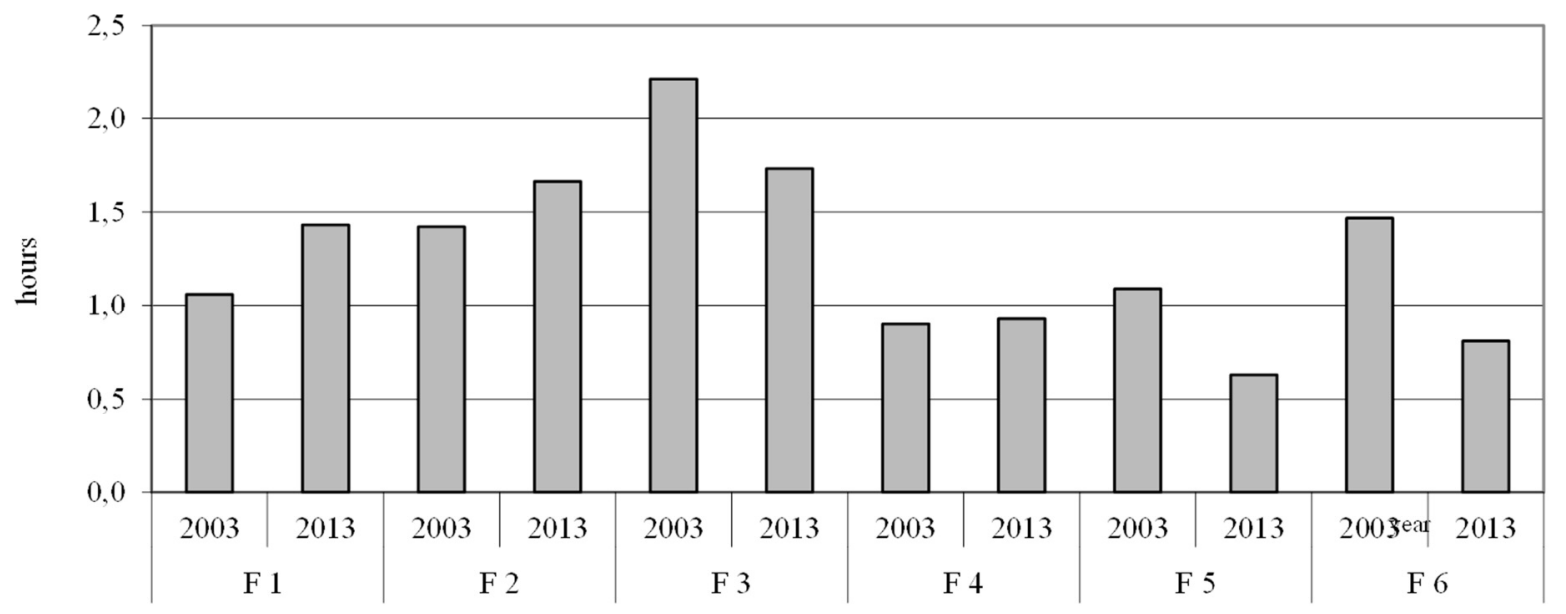

$\square$ work hours per 100 litres of milk

Note: F1; F2; F3; F4; F5; F6: Farms 


\section{CONCLUSIONS AND RECOMMENDATIONS}

- Human and technical resources together with the dairy stock as production factors influence productivity.

- The developments and investments on the farms in study contributed to the decreasing number of workers despite the increasing number of cows.

- All of the farms in study made investments in the ten-year period, and most of them used a significant amount of funding through proposals.

- We can conclude that there are still differences between farms of equal size, so there are still ways of development.

- The productivity index of the number of cows per physical workers increased on the farms with increasing number of cows.
- The number of cows per physical workers has not increased in direct ratio with the increasing number of cows.

- Some work productivity indices show $100 \%$ differences between certain farms.

- The best productivity on all three indices is experienced on farm F5 and the worst is on farm F3.

- The greatest progress in productivity was realized on farms with the greatest amount of investments in the ten-year period.

- It is recommended to the farms to apply for funds in order to improve their enterprise.

- In order to improve their productivity farms should share experiences and apply others' good farming practices.

\section{REFERENCES}

Bácsné Bába É. (2013): Hogyan növelhető a menedzserek személyes hatékonysága? Virtuális Intézet Közép-Európa Kutatására Közleményei. No. 12. A-sorozat 4. - Gazdálkodás- és szervezéstudományi tematikus szám. 5. 1: 131-137.

Fülöp S. (2003): Menedzsment technikák - termelési menedzsment kis- és középvállalkozási gyakorlata. BGF PSZFK Management Tanszék. Budapest. 65.

Gergely É. (2011): A teljesítmény-menedzsment gyakorlata a vállalati szférában. Erdei Ferenc VI. Tudományos Konferencia. Kecskemét. 3: 13-17.

Gulyás L.-Keczer G. (2012): Projektmenedzsment 1.0. [In: Gulyás L. (szerk.) Közép-Európai Monográfiák.] Egyesület Közép-Európa Kutatására. Szeged-Pécs.

Hagymássy Z.-Gindert-Kele Á. (2011): Fotoelektromos energiatermelő rendszer üzemeltetésének tapasztalatai. Miskolci Egyetem Multidiszciplináris tudományok. 1. 1: 229-234.

Harsányi E.-Fejér P. I.-Kutasiné Nagy I.-Rátonyi T. (2014): A vidékiség értelmezése és a földhasználat helyzete Magyarországon. Agrártudományi Közlemények. 79-85.

Harsányi E.-Harsányi G.-Nagy A. J. (2005): Területi fejlettségi különbségek az Észak-alföldi régióban. Agrártudományi Közlemények. 16: 170-180.

Hüttl A. (2010): Termelékenység a magyar gazdaságban. TM 63. sz. mühelytanulmány. Versenyképesség kutatás mühelytanulmány sorozat. BCE Versenyképesség Kutató Központ. Budapest. 44.

Kupán E. (2007): Az agrárstruktúra és agrártermelés fejlesztésének lehetôségei és irányai Maros megyében. Doktori $\mathrm{PhD}$ értekezés. Budapesti Corvinus Egyetem. Budapest. 158.

Mező B. (2012): Hajdúböszörmény településszerkezeti sajátossága és társadalmi folyamatai az ezredforduló után. Agrártudományi Közlemények. 47: 49-56.

Nagy J.-Sinóros-Szabó B.-Harsányi G.-Nagy O.-Harsányi E. (2014): A vidékfejlesztés államháztartási forrásai és terület megoszlása. Agrártudományi Közlemények. 73-77.

Net1: Musinszki Z.: A mezőgazdasági tevékenység elemzése. http:// gtk.uni-miskolc.hu/files/2161/mez\%C5\%91gazdas\%C3\%A1g. pdf

Net2: Állattartó telepek korszerüsítése. http://www.szilberhorn.com/ allattarto-telepek-korszerusitese.html

Net3: A precíziós növénytermelés alkalmazása Magyarországon. http://napok.georgikon.hu/cikkadatbazis-2012-2013/doc_view/ 56-lencses-eniko-a-precizios-novenytermeles-alkalmazasamagyarorszagon
Net4: Kiemelten fontos feladat az állattenyésztés támogatása. http:// www.kormany.hu/hu/foldmuvelesugyi-miniszterium/hirek/ fontos-a-tenyesztesi-szuverenitas-megorzese

Net5: Az állattenyésztés nyertese lesz a 2014-2020-as ciklusnak. http://www.palyazatihirek.eu/mezogazdasagi-palyazatok/2693az-allattenyesztes-nyertese-lesz-a-2014-2020-as-ciklusnak10025024

Pierog A.-Szabados Gy. (2012): A vezetés és döntés sajátosságai civil szervezetekben. VIKEK Közlemények. 4. 2: 59-65.

Popp J.-Vőneki É.-Papp G. (2007): A hazai tejvertikum versenyképessége az EU-ban és a világgazdaságban. [In: Kovács K (szerk.) Ágazatspecifikus innováción alapuló projektek generálása a tejágazatban.] Szaktanácsadási füzetek. Debreceni Egyetem. 12: 36 .

Rózsás T. (2007): Versenyképes Magyarország, magasabb életszínvonal. Polgári Szemle. 3: 6.

Salamon L.-Tell I.-Kacz K.-Hegyi J. (2011): Növénytermesztési ágazatok ökonómiája - A mezőgazdasági vállalatok termelési szerkezete. http://www.tankonyvtar.hu/hu/tartalom/tamop425/ 0010_1A_Book_18_Novenytermesztesi_agazati_okonomia/ ch03.html

Seregi J.-Kis Z. (2014): Az állattenyésztési kapacitás fogalma és szerepe a régiókban. Taylor Gazdálkodás- és szervezéstudományi folyóirat. VIKEK Közlemények. 6. 3-4: 350-356.

Sulyok, D.-Ferencsik, S.-Rátonyi, T.-Huzsvai, L.-Nagy, J. (2013): Agronomical and agro-economic evaluation of maize production in various cultivation systems. Növénytermelés - Supple. 62 : $33-36$.

Sutus I. (2012): Mezőgazdasági vállalkozások könyvvizsgálatának speciális feladatai. Magyar Könyvvizsgálói Kamara Ágazati Módszertani Füzetek. Magyar Könyvvizsgálói Kamara. Budapest. 202.

Szabó F. (2013): Az európai és hazai fejlesztési politikák, az Uniós támogatások 2007-2013 között, a kohéziós politika jövője. VIKEK. B-sorozat 2. Társadalomtudományi tematikus szám. 5. 2: 207-212.

Terjék, L. (2010): Contentment-analysis of work environment is ways of safety at agricultural companies leaders and workers in Hajdú-Bihar County. Jelenkori társadalmi és gazdasági folyamatok. 5. 1-2: 1788-7593

Vámosi T. (2011): Képzés, tudás, munka. A magyar szak- és felnőttképzési rendszer szerepe és funkciója a társadalmi-gazdasági térben a 21. szd. elején. Új Mandátum Könyvkiadó. Budapest. 63. 
Vántus, A.-Hagymássy, Z. (2014): Connection between human resource and technical equipment and importance of these factors in production. Taylor Gazdálkodás- és szervezéstudományi folyóirat. VIKEK Közlemények. 6. 3-4: 134-139.
Ványiné Széles, A.-Bogdán, I.-Sulyok, D.-Nagy, J. (2012): The effect of fertilisation and irrigation on the yield of different genotype maize hybrids and the economic aspects of production. [In: Halasi-Kun, G. J. (ed.) Impact of Anthropogenic Activity and Climate Changes on the Environment of Central Europe and USA.] Columbia University. University Seminars. 341-360. 